\title{
Feasibility of using sodium alginate for improving structural quality of
} sweet dahi

\author{
Islam MN*, S Arefin, MAH Sarker, S Akhter, R Habib
}

Department of Dairy Science, Bangladesh Agricultural University, Mymensingh 2202, Bangladesh

\begin{abstract}
Dahi is a popular fermented milk product with higher nutritional value and significant therapeutic properties. The objective of the present study was to use sodium alginate as stabilizer to monitor the feasibility of using for improving structural quality of sweet dahi. Dahi were prepared using $0.4 \%, 0.6 \%$, $0.8 \%$ and $1 \%$ sodium alginate. One control sample was made with no stabilizer to judge the other treated samples. All the samples were analyzed for organoleptic and chemical qualities .Significant difference was found in case of smell \& taste score $(p<0.05)$, body \& consistency $(p<0.01)$, color $(p<0.01)$. Highest $(p<0.05)$ smell and taste score was found at $0.6 \%$ sodium alginate treated dahi. In case of body \& consistency $0.6 \%$ sodium alginate showed better results. In case of color, $0.6 \%$ level of sodium alginate $(p<0.01)$ showed nearly similar result as dahi with no sodium alginate. Significant $(p<0.01)$ differences were found among the treatments in case of composition of dahi samples, except for the fat content, which showed insignificant $(p>0.05)$ difference. Total solids, ash and protein content of dahi samples were increased after addition of sodium alginate. From the above analysis $0.6 \%$ sodium alginate was found to be better and it can be concluded that sodium alginate can be used as stabilizer to improve the structural quality of dahi.
\end{abstract}

Key words: stabilizer, composition, organoleptic qualities, chemical qualities Bangladesh Animal Husbandry Association. All rights reserved. $\quad$ Bang. J. Anim. Sci. 2016. 45 (2): 66-72

\section{Introduction}

The nutritional and potentially therapeutic value of food is a key characteristic in the development of new value-added products manufactured for health conscious consumers (Garcia et al. 1998). Dahi is one of the most popular fermented milk products worldwide and has gained widespread consumer acceptance as a healthy food (Mckinley 2005). Dahi is a fermented milk product obtained by lactic acid fermentation through the action of Lactobacillus bulgaricus and Streptococcuc thermophillus with one or more other optional ingredients as sugar, stabilizers and colours. It can be made either with whole milk or skim milk. When whole milk is used, it has a creamy layer on top, the rest being made up to a homogeneous body of curd. The stabilizers are used to improve the consistency, viscosity and reduce the synersis rate (Lucey, 2002). Different stabilizers are used to create desired texture and stability during processing and storage of dahi. Selection of the stabilizer or stabilizer combination to be used in a food system greatly depends on several variables.

*Corresponding author: mnislamds@yahoo.com
The stabilizers are classified into following groups as plant extract (pectin), seed flour (guargum), cellulose derivatives (carboxyl methyl cellulose), seawood extracts (carragenan and sodium alginate) cereal starches, corn starch and gelatin (Athar et al. 2000). Stabilizers have been used in food products for a variety of purposes, including thickening, aiding stability, and improving mouthfeel (Harris, 1990; Phillips and Williams, 2000). In yoghurt, stabilizers are added for two main reasons as thickening or gelling agents and to stabilize the yogurt matrix (Early, 1998; Phillips and Williams, 2000; Tamime and Robinson, 1999). In this capacity, the hydrocolloids, which are generally added to the milk prior to fermentation, can improve the viscosity, maintain the yogurt structure, inhibit syneresis, alter the mouthfeel, and in the case of yogurt with added fruit, help keep the fruit in suspension (Early, 1998). Gelatin, carboxymethy Icellulose, and high methoxy pectin all may be used to achieve these results.

Sodium alginate is a substance that the Food and Drug Administration has listed as generally 
recognized as safe. In production, sodium alginate is extracted from brown algae and is the sodium salt of alginic acid. It is highly viscous and is often used as an emulsifier and a gelling agent. It is a flavorless gum made from brown kelp grown in the cold water regions. It is used in the food industry to increase viscosity and as an emulsifier. Sodium alginate is used in ice cream to assure a creamy texture and prevent formation of ice crystals. Stabilizer can influence the texture quality of dahi, but no research work has yet been done in our country to evaluate feasibility of using stabilizer on improving the texture of dahi. Keeping in view the structural property, it was planned to use sodium alginate as stabilizing agent in dahi to evaluate its influence on the composition, texture and sensory characteristics.

\section{Materials and Methods}

\section{Site and time of experiment}

The experiment was carried out at the Dairy Technology Laboratory of the Department of Dairy Science, Bangladesh Agricultural University, Mymensingh-2202, Bangladesh during the period of 14 September to 27 November.

\section{Using raw milk and sodium alginate}

Whole milk was collected from the Bangladesh Agricultural University Dairy farm. Sodium alginate (UC-S31870-3I, Cas No. 9005-38-3, Lot No. GD 7103428, made in China) was used as stabilizer in dahi.

\section{Preparation of sodium alginate solution $\left(\mathrm{C}_{6} \mathrm{H}_{9} \mathrm{NaO}_{7}\right)$}

In a clean cup about $10 \mathrm{ml}$ of hot water was taken and $2 \mathrm{gms}$ of sodium alginate powder was dissolved. When the powder was soaked completely then $15 \mathrm{ml}$ hot water was added and kept the solution 10-15 minutes before further use.

\section{Preparation of different types of dahi}

Five different types of dahi were prepared. These were type $A$, dahi without sodium alginate (control); type $B$, dahi with added $0.4 \%$ sodium alginate; type $C$, dahi with added $0.6 \%$ sodium alginate; type $\mathrm{D}$, dahi with added $0.8 \%$ sodium alginate; type $\mathrm{E}$, dahi with added $1.0 \%$ sodium alginate.

The collected $500 \mathrm{~mL}$ whole milk was heated to boiling temperature. At the time of boiling, sugar was added to the milk at the rate of $12 \%(60 \mathrm{~g})$. During heating, milk was stirred thoroughly with the help of stirrer. After desired heating milk pan was taken out from the heater and allowed to cool down to $40{ }^{\circ} \mathrm{C}$ and then in a $500 \mathrm{ml}$ beaker $480 \mathrm{ml}$ heated milk was taken and starter culture was added to the milk at the rate of $2 \%$ by weight. Starter culture was dissolved properly by stirring it and then milk was poured in several pre-boiled water wash plastic cups of about 100 $\mathrm{mL}$ size and kept in undisturbed condition at an incubation temperature of $42{ }^{\circ} \mathrm{C}$ for 6 to 8 hours to complete coagulation of the sample. After complete coagulation, the dahi samples were taken out from the incubator and stored in a refrigerator at about $5^{\circ} \mathrm{C}$ for analytical purpose. This type of dahi was identified as ' $A$ ' type (control) dahi for experimental purpose. For the preparation of sodium alginate treated dahi by using different percentage of sodium alginate such as $0.4 \%, 0.6 \%, 0.8 \%$ and $1 \%$ to make type $B, C, D$ and $E$ respectively. For this purpose at the time of boiling, sugar was added to the rate of $12 \%(60 \mathrm{~g})$ in each case and different percentage of sodium alginate solution such as (2 $\mathrm{g}+10 \mathrm{~mL}),(3 \mathrm{~g}+50 \mathrm{~mL}),(4 \mathrm{~g}+75 \mathrm{~mL})$ and $(5$ $\mathrm{g}+100 \mathrm{~mL}$ ) were used to make type B, C, D and $\mathrm{E}$ respectively. Then starter culture was added to the milk at the rate of $3 \%$ in each type. After that, the same procedure was followed in the preparation of dahi which was followed to make control sample.

\section{Physical test}

Physical quality was evaluated with the help an expert panel of judges $(n=08)$ of the teachers' of Dairy science department of BAU using a score card which consisted of smell and taste (50), body and consistency (30), colour and texture (20).

\section{Chemical test}

After the organoleptic evaluations all dahi samples were chemically analyzed to know acidity percentage, $\mathrm{pH}$ values, total solids $(\mathrm{g} / \mathrm{kg})$, moisture $(\mathrm{g} / \mathrm{kg})$, protein $(\mathrm{g} / \mathrm{kg})$, fat $(\mathrm{g} / \mathrm{kg})$, carbohydrate $(\mathrm{g} / \mathrm{kg})$ and ash $(\mathrm{g} / \mathrm{kg})$. Total solids and ash content of the dahi samples were 
determined by oven drying and incineration method according to AOAC (2003). Fat \% was estimated by Babcock method. Acidity was determined by titrating with $\mathrm{N} / 10$ sodium hydroxide solution. Crude protein was determined by Kjeldahal procedure as per AOAC (2003) and $\mathrm{pH}$ was measured with the help of a $\mathrm{pH}$ meter215 (Ciba Corning Diagnostics Ltd, Sudhury, Suffolk, England Co. 106×D).

\section{Initial quality of milk}

It is mentioned earlier that milk used in this experiment was collected from Bangladesh Agricultural University Dairy Farm. The initial quality of milk was monitored before starting the experiment for getting idea about the quality of milk used (table 1 ).

\section{Data analysis}

Statistical differences among different levels of dahi samples were found out using one way analysis of variance (ANOVA). The statistical analyses were done using Statistical Package for the Social Science (SPSS) version-16. In case of significant differences DMRT was considered.

\section{Results and Discussion}

\section{Organoleptic evaluation of dahi}

\section{Smell and taste}

Variations in the score for smell and taste due to different treatments $(A, B, C, D$ and $E$ ) was found to be significant $(p<0.05)$. But a higher smell and taste score $(45.25 \pm 0.95)$ was found at $0.6 \%$ sodium alginate incorporated dahi (Table 2). This score was 1.04 times higher than control one. Morover, it was noticeable that the smell and taste scores were gradually deceased in accordance with the increased percentage of sodium alginate in dahi. The results indicate that if sodium alginate is used at $0.6 \%$ as stabilizer, smell and taste of dahi is increased up to certain level, but if more than the used level, smell and taste score of dahi decreased. Parveen (2004) reported that some stabilizers not only stabilize the product but also used as fat replacers like malodextrin which gives better taste, appearance and also reduce syneresis. Alakali et al. (2008) showed that yoghurt containing carboxyl methyl cellulose (CMC) at $0.75 \%$ concentration gives the most desirable flavour and taste with $0.75 \%$ corn starch. Agarwal et al. (2013) found desirable characteristic flavor in dahi using carrot pulp as stabilizer at different levels.

Table 1. Initial quality of raw whole milk collected from BAU dairy farm

\begin{tabular}{ll}
\hline Parameters studied & Initial quality of milk \\
\hline Fat $(\mathrm{g} / \mathrm{kg})$ & $43.0 \pm 1.7$ \\
SNF $(\mathrm{g} / \mathrm{kg})$ & $79.5 \pm 2.1$ \\
Protein $(\mathrm{g} / \mathrm{kg})$ & $35.6 \pm 2.5$ \\
$\mathrm{TS}(\mathrm{g} / \mathrm{kg})$ & $122.5 \pm 1.8$ \\
Water $(\mathrm{g} / \mathrm{kg})$ & $877.5 \pm 1.8$ \\
Specific gravity & $1.028 \pm 0.001$ \\
Color $(\%$ of normal/abnormal) & Normal $100 \%$ \\
& (yellowish white) \\
Flavor (\% of normal/abnormal) & (pormal $100 \%$ \\
Clot on Boiling test (COB) & $(-$ ve) \\
Acidity & $0.14 \pm 0.009$ \\
\hline
\end{tabular}

\section{Body and texture}

Different treatments ( $, B, C, D$ and $E$ ) differed significantly $(p<0.05)$ in case of body and texture of dahi with different levels of sodium alginate. The most defects related to yogurt texture that may lead to consumer rejection are variations in initial viscosity and the occurrence of excessive syneresis (Kroger, 1975). The texture quality which was achieved through this experiment is shown in Figure 1. Dahi treated at $0.6 \%$ sodium alginate showed best appearance. The lowest body and texture score was recorded in control group (Table 2). Among the treated dahi the $\mathrm{E}$ type at $1 \%$ sodium alginate was appeared with more 7 score in body and texture than control group. Stabilizer levels had significant effect on body and texture of yoghurt. Although the body and texture score increased with addition of sodium alginate, but it was found that the score for $0.6 \%$ sodium alginate treated dahi was nearly similar to A type (control) dahi. Hasan et al. (2014) got highest points for body and texture; there was least decrease in body and texture for $0.25 \%$ of Meteroxylon sagu as stabilizer. These results are in accordance with previous findings (Basset, 1983). Agarwal et al. (2013) also explained that the highest score of 8.2 was recorded at $0.5 \%$ level of stabilizer with carrot pulp indicating that the frozen yoghurt at $0.5 \%$ stabilizer was the best quality product with firm body and smooth texture. 
Table 2. Organoleptic evaluation scores of dahi made by adding different levels of sodium alginate

\begin{tabular}{|c|c|c|c|c|c|c|}
\hline \multirow{2}{*}{ Parameters studied } & \multicolumn{5}{|c|}{ Type of dahi (Mean \pm SD) } & \multirow{2}{*}{$\begin{array}{c}p \\
\text { value }\end{array}$} \\
\hline & A & $B$ & $\mathrm{C}$ & $\mathrm{D}$ & $E$ & \\
\hline Smell and taste $(50)$ & $43.75^{\mathrm{ab}} \pm 1.50$ & $44.25^{\mathrm{ab}} \pm 0.95$ & $45.25^{\mathrm{a}} \pm 0.95$ & $43.25^{b} \pm 0.95$ & $42.75^{b} \pm 0.95$ & 0.046 \\
\hline Body and texture (30) & $23.00^{d} \pm 0.81$ & $24.00^{\mathrm{cd}} \pm 0.81$ & $25.00^{\mathrm{bc}} \pm 0.81$ & $26.00^{\mathrm{ab}} \pm 0.81$ & $27.00^{\mathrm{a}} \pm 0.70$ & 0.000 \\
\hline Color and appearance (20) & $18.75^{a} \pm 0.50$ & $17.00^{b} \pm 0.70$ & $16.50^{b} \pm 0.57$ & $15.00^{c} \pm 1.08$ & $14.50^{c} \pm 0.70$ & 0.000 \\
\hline Overall score $(100)$ & $85.25^{\mathrm{ab}} \pm 1.55$ & $85.62^{\mathrm{ab}} \pm 1.10$ & $86.87^{\mathrm{a}} \pm 0.85$ & $84.25^{b} \pm 0.95$ & $84.50^{b} \pm 0.40$ & 0.021 \\
\hline
\end{tabular}

Different letters mean type of dahi $\mathrm{A}$, dahi without sodium alginate (control); $\mathrm{B}$, dahi with added $0.4 \%$ sodium alginate; $\mathrm{C}$, dahi with added $0.6 \%$ sodium alginate; $D$, dahi with added $0.8 \%$ sodium alginate and $E$, dahi with added $1.0 \%$ sodium alginate. Different superscripts $a, b$, C, means differ values significantly within same row. ${ }^{*}$ Significant at $1 \%$ level $(P<0.01)$; ${ }^{*}$ Significant at $5 \%$ level $(P<0.05)$; NS, nonsignificant $(P>0.05)$.

Table 3. Chemical evaluation of dahi made by adding different levels of sodium alginate

\begin{tabular}{lllllll}
\hline \multirow{2}{*}{$\begin{array}{l}\text { Chemical } \\
\text { parameters }\end{array}$} & \multicolumn{7}{c}{ Types of dahi } \\
\cline { 2 - 7 } & \multicolumn{1}{c}{ A } & \multicolumn{1}{c}{ B } & \multicolumn{1}{c}{ C } & \multicolumn{1}{c}{ D } & \multicolumn{1}{c}{ E } & P value \\
\hline TS $(\mathrm{g} / \mathrm{kg})$ & $263.33^{\mathrm{d}} \pm 5.77$ & $273.33^{\mathrm{dc}} \pm 5.77$ & 5.77 & $276.66^{\mathrm{c}} \pm$ \\
Fat $(\mathrm{g} / \mathrm{kg})$ & $42.66 \pm 0.67$ & $41.00 \pm 1.00$ & $41.83 \pm 0.57$ & $41.50 \pm .50$ & $41.60 \pm 0.92$ & 0.133 \\
Protein $(\mathrm{g} / \mathrm{kg})$ & $38.12^{\mathrm{c}} \pm 0.13$ & $38.18^{\mathrm{c}} \pm 0.08$ & $38.40^{\mathrm{c}} \pm 0.10$ & $39.20^{\mathrm{b}} \pm 0.26$ & $40.10^{\mathrm{a}} \pm 0.10$ & 0.000 \\
CHO $(\mathrm{g} / \mathrm{kg})$ & $44.66^{\mathrm{c}} \pm 0.56$ & $47.00^{\mathrm{b}} \pm 1.00$ & $50.00^{\mathrm{a}} \pm 1.00$ & $50.00^{\mathrm{a}} \pm 1.00$ & $51.00^{\mathrm{a}} \pm 1.00$ & 0.000 \\
Ash $(\mathrm{g} / \mathrm{kg})$ & $7.30^{\mathrm{e}} \pm 0.06$ & $9.10^{\mathrm{d}} \pm 0.10$ & $10.20^{\mathrm{c}} \pm 0.1$ & $11.37^{\mathrm{b}} \pm 0.15$ & $12.26^{\mathrm{a}} \pm 0.14$ & 0.000 \\
Acidity $(\%)$ & $0.71^{\mathrm{a}} \pm 0.01$ & $0.65^{\mathrm{b}} \pm 0.01$ & $0.61^{\mathrm{c}} \pm 0.01$ & $0.58^{\mathrm{c}} \pm 0.02$ & $0.52^{\mathrm{d}} \pm 0.02$ & 0.000 \\
PH & $4.06^{\mathrm{d}} \pm 0.05$ & $4.16^{\mathrm{cd}} \pm 0.05$ & $4.23^{\mathrm{cd}} \pm 0.05$ & $4.33^{\mathrm{ab}} \pm 0.05$ & $4.43^{\mathrm{a}} \pm 0.05$ & 0.000 \\
\hline
\end{tabular}

Different letters mean type of dahi. A, dahi without sodium alginate (control); $\mathrm{B}$, dahi with added $0.4 \%$ sodium alginate; $\mathrm{C}$, dahi with added $0.6 \%$ sodium alginate; $D$, dahi with added $0.8 \%$ sodium alginate and $E$, dahi with added $1.0 \%$ sodium alginate. Different superscripts $a, b$, C, means differ values significantly within same row. ${ }^{*}$ Significant at $1 \%$ level $(P<0.01)$; ${ }^{*}$ Significant at $5 \%$ level $(P<0.05)$; NS, nonsignificant $(P>0.05)$.

\section{Color and appearance}

Significant $(p<0.01)$ differences were found among different treatments $(A, B, C, D$ and $E)$ in color and appearance of dahi. The color and appearacne score was hound to be highest in $A$ tpe dahi followed by B, C, D and the lowest score in the $\mathrm{E}$ type dahi. The color and appearance gradually decreased in accordance with the increased percentage of sodium alginate. It was found that the score for $0.4 \%$ and $0.6 \%$ sodium alginate treated dahi was nearly similar to A type dahi. Agarwal et al. (2013) found that the frozen yoghurt with $1.5 \%$ stabilizer and $3 \%$ carrot pulp recorded highest mean score of 8.6 for general appearance. Alakali et al. (2008) found that the addition of $0.5-0.75 \%$ carboxyl methyl cellulose (CMC) caused the production of the most desirable appearance that differed significantly ( $p$ $<0.05$ ) from control one.

\section{Overall score}

The overall scores of various types of dahi sample were calculated on the basis of average scores recorded for different organoleptic analysis by using score card. The overall scores of smell and taste, body and texture, color and appearance were recorded for $A, B, C, D$ and $E$ type dahi samples, respectively (Table 2). Statistical significant differences $(p<0.05)$ were found among the overall score of dahi samples. The highest score was obtained in case of sample $\mathrm{C}$ type $(0.6 \%$ sodium alginate). On the other hand, lowest score was obtained at $\mathrm{E}$ type dahi ( $1 \%$ sodium alginate). The result of this experiment indicates that if we use sodium alginate as stabilizer, overall score of dahi is increased up to certain level at $0.6 \%$ Sodium alginate. But if we add more than this level overall score of dahi is decreased gradually. Hussein et al. (2011) found that $0.1 \%$ of polysaccharides as stabilizer which 
extracted from okra had gained the highest total scoring degree. Another research found that thermized yoghurt produced without any stabilizer had significantly $(p<0.05)$ the least overall acceptability as it was disliked much but the addition of $0.75 \%$ carboxyl methyl cellulose (CMC) produced thermized yoghurt that was significantly $(p<0.05)$ higher acceptability than others. (Alakali et al., 2008).

\section{Chemical evaluation of dahi}

\section{Total solids}

Statistical analysis showed that effect of different amount of stabilizers was highly significantly $(p<0.01)$ differed for total solids (TS) of dahi. The total solids of dahi treated with $1 \%$ sodium alginate were found to be higher with $47 \mathrm{~g} / \mathrm{Kg}$ by weight than the control one. TS content of dahi was trend to be increased with the increasing percentage of sodium alginate. The result is in agreement with the finding of Mehmood et al. (2008) who reported that the maximum total solids were found with the addition of $0.5 \%$ guar gum followed by with the addition of combination of $0.5 \%$ carboxyl methyl cellulose (CMC) and $0.5 \%$ corn starch as stabilizer. Khalifa et al. (2011) reported that the addition of $0.2 \%$ mucilage gives the highest total solids followed by inulin $6 \%, 4 \%$ than control. Alakali et al. (2008) reported that yoghurt containing corn starch significantly ( $p<0.05$ ) possessed the highest TS followed by gelatin while carboxyl methyl cellulose (CMC) was the least. The findings of the research also revealed that the total solids contents of samples significantly $(p<$ 0.05 ) increased with increase in concentration of the stabilizers because the stabilizers are solids themselves.

\section{Fat}

Dahi treated with different levels of sodium alginate $(A, B, C, D$ and $E)$ were statistically similar $(p>0.05)$. Alakali et al. (2008) reported that with the addition of different stabilizers in yoghurt, the fat parentage were statistically similar ( $p>0.05)$ among the treatments. However, $1.0 \%$ gelatin and $1.0 \%$ corn starch recorded marginaly increases due to residual oil in corn starch and gelatin.

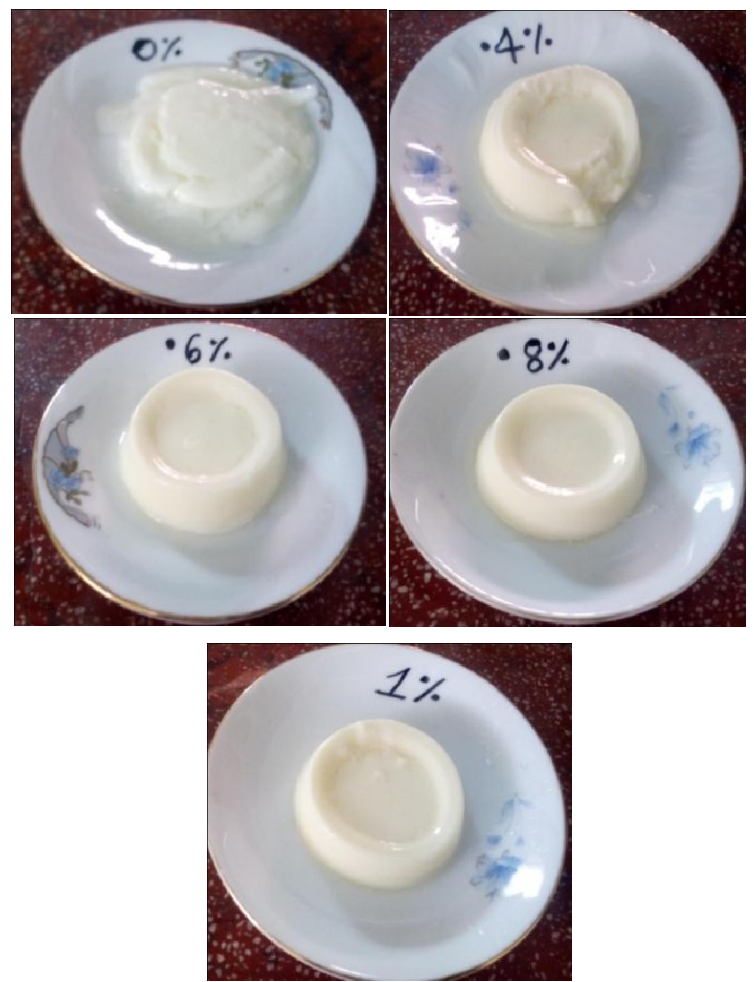

Figure 1. Body and texture of dahi adding with different levels of sodium alginate

\section{Protein}

Sodium alginate showed a significant $(p<0.05)$ effect in protein percentage of dahi. The protein content was increased in dahi through addition of sodium alginate. Mehmood et al. (2008) reported that using different types of stabilizers, the highest protein content was found for inulin $6 \%$ followed by $0.2 \%$ mucilage and the lowest protein content was found for inulin $4 \%$ and control. On the other hand, Alakali et al. (2008) found decreased protein percentage with the addition of different types of stabilizers (carboxyl methyl cellulose, gelatin, corn starch). He stated that this may be related to the small proportions of the stabilizers used and the fact that CMC and corn starch have little protein contents.

\section{Carbohydrates}

Carbohydrates content significantly $(p<0.05)$ increased among the treatments $(A, B, C, D$ and E) after addition of sodium alginate in dahi (Table 2). This increased percentage may be due to the carbohydrates contents in sodium alginate. Khalifa et al. (2011) stated that irrespective of 
the storage periods, the highest ( $p=0.05$ ) carbohydrates content was observed for mucilage $0.2 \%$ treated yoghurt compared to the control, inulin $4 \%$ and inulin $6 \%$ treated yoghurt samples. They stated that mucilage has a better performance in keeping higher carbohydrate content and that might be explained by the fact that mucilage has higher carbohydrate precursors. Athar et al. (2000) reported that at initial day, yoghurt using different stabilizers such as pectin, guargum, CMC, carrageenan, sodium alginate, cornstarch and gelatin at $0.4 \%$ level showed differences in case of carbohydrates content.

\section{Ash}

Ash content in dahi significantly $(p<0.05)$ increased among the treatments $(A, B, C, D$ and $E)$. Ash content increased in accordance with the increased percentage of sodium alginate. The highest ash content was recorded at $1.0 \%$ sodium alginate treated dahi. In this experiment, this result may be achieved through higher sodium content as mineral in sodium alginate. This result agrees with the findings of Alakali et al. (2008.) They found increased ash content by using carboxy methyl cellulose (CMC), gelatin and corn starch as stabilizer in thermized yoghurt. Khalifa et al. (2011) found that irrespective of storage period the ash content of all yoghurt samples were similar, showing no differences $(p<0.05)$. In the experiment inulin $4 \%, 6 \%$ and mucilage $0.2 \%$ were used.

\section{Acidity}

As shown in Table 2, titrable acidity of dahi significantly $(p<0.05)$ decreased found among the treatments $(A, B, C, D$ and $E)$. This lowering percentage in titrable acidity might be for increased percentage of sodium alginate. Mehmood et al.(2008) found that with the addition of different levels $(0.1 \%, 0.2 \%, 0.3 \%, 0.4$ and $0.5 \%$ ) of carboxyl methyl cellulose, gelatin, corn starch, guar gum or their combination give lower titratable acidity with their increased concentration in initial days whereas give higher titratable acidity in 21 days. Khalifa et al. (2011) noticed higher titatable acidity of yoghurt treated with inulin $6 \%$ than that produced with inulin $4 \%$, however still less than that of mucilage $0.2 \%$.

\section{pH value}

$\mathrm{pH}$ of dahi differed significantly $(\mathrm{p}<0.05)$ among the treatments $(A, B, C, D$ and $E)$. The $p H$ value increased in accordance with the addition of sodium alginate. Hasan et al. (2014) found significant results of $\mathrm{pH}$ at concentration of $0.1 \%$, $0.25 \%$, and $0.50 \%$ of Metroxylon sagu compared with $0.5 \%$ gelatin in yoghurt. Athar et al. (2000) showed that optimum $\mathrm{pH}$ was found as 4.248 and 4.236 in case of $0.4 \%$ cornstarch and $0.4 \%$ gelatin, respectively at initial day of storage in compared to pectin , guargum, CMC, carrageenan and sodium alginate which ranged from 4.143 to 4.170 .

\section{Conclusion}

Based on the result of the present study, it can be concluded that sodium alginate can be used successfully to improve structural quality of dahi. A level of $0.6 \%$ sodium alginate was found suitable for this purpose. It was also observed that sodium alginate enhanced the total solids, ash and protein content of dahi.

\section{References}

Agarwal S and Prasad R (2013). Effect of stabilizer on sensory characteristics and microbial analysis of low fat frozen yoghurt incorporated with carrot pulp. International Journal of Agriculture and Food Science Technology, 4(8):797-806.

Alakali JS, Okonkwo TM and Iordye EM (2008). Effect of stabilizers on the physico-chemical and sensory attributes of thermized yoghurt. African Journal of Biotechnology, 7(2): 158163.

AOAC (2003). Official Methods of Analysis. $10^{\text {th }}$ Edition. Association of Official Agricultural Chemists. Washington DC, USA.

Athar IH, Shah MA, Khan UN (2000). Effect of various stabilizers on whey separation (syneresis) and quality of yoghurt. Pakistan Journal of Biologiacl Sciences, 3(8):13361338.

Bassett HJ (1983). Use of stabilizers in cultured dairy foods. Cultured Dairy Products, 18(1): 27-30.

Early R (1998). The Technology of Dairy Products. (Second edition), International Thomson publishing, An Imprint of Chapman and Hall, England.

Garcia EF, McGregor JU and Traylor S (1998). Addition of Oat Fiber and Natural Alternative Sweeteners in the Manufacture of Plain 
Yoghurt. Journal of Dairy Science, 81:655663.

Harris P (1990). Food gels. Elsevier Science Publishers Ltd. Essex, UK.

Hasan N, Huma N, Sameen A, Rafiq S, and Gulzar N (2014). Use of meteroxylon sagu as a stabilizing agent in yoghurt. Journal of Food Chemistry and Nutrition, 2(1): 19-26.

Hussein MM, FAM Hassan, Abdel Daym $\mathrm{HH}$ Salama A, Enab AK, Asmaa A, Abd El-Galil (2011). Utilization of some plant polysaccharides for improving yoghurt consistency. Annals of Agricultural Science, 56(2): 97-103.

Khalifa MEA, Elgasim $A E$, Zaghloul $A H$ and Mahfouz MB (2011). Application of inulin and mucilage as stabilizers in yoghurt production. American Journal of Food Technology, 6 (1): 31-39.

Kroger M (1975). Quality of yogurt. Journal of Dairy Science, 59 (2): 344-350.

Lucey JA (2002). Formation and physical properties of milk protein gels. Journal of Dairy Science, 85(2): 281-294.

McKinley MC (2005). The Nutrition and health benefits of yogurt. International Journal of Dairy Technology, 58: 1-12.
Mehmood ST, Masud T, Mahmood T and Maqsud $S$ (2008). Effect of different additives from local source on the quality of yoghurt. Pakistan Journal of Nutrition, 7 (5): 695-699.

Parveen A (2004). Influence of strawberry on the quality and acceptability of fruit yoghurt. MS Thesis, Department of Food Technology, University of Agriculture, Faisalabad.

Phillips GO and Williams PA (2000). Handbook of hydrocolloids. Boca Raton, Fla.: CRC Press; Cambridge:Woodhead, - Woodhead Publishing series in food science and technology.

Shukla FC, Jain SC and Sandhu KS (1987). Effect of stabilizers and additives on the diacetyl and volatile fatty acids content of yoghurt. Indian Journal of Dairy Science, 40(1): 486488.

SPSS (Statistical Package for the SocialSciences)16, Released in (2007). SPSS for Windows, Version 16.Chicago, SPSS Inc.

Tamime AY and Robinson RK (1999). Yoghurt Science and Technology, 2nd Edition. Boca Raton, New York, Washington, DC. Woodhead Publishing Limited. 